\title{
Базові принципи хірургічного лікування рецидиву післяопераційної грижі живота після алопластики
}

\begin{abstract}
Мета роботи: вивчення причин виникнення рецидиву післяопераційної грижі живота (ПГЖ) після алопластики і розробка практичних рекомендацій для поліпшення результатів хірургічного лікування пацієнтів із даною патологією.

Матеріали і методи. За період з 2004 до 2019 рр. у Київському міському центрі хірургії гриж живота з приводу рецидивної ПГЖ після алогерніопластики прооперовано 133 пацієнти: чоловіків - 23 (17,3\%), жінок - 110 (82,7 \%). Середній вік пацієнтів становив $(59,4 \pm 0,8)$ року. Пацієнти з ПГЖ за класифікацією SWR [8] розподілилися таким чином: хворих із M2-3W1R1 було 80 (60,15 \%), M3-5W2R1 - 40 (30,1 \%), M3-5W3R2 - 3 (2,25 \%), L3W2R1 - 6 (4,5 \%), L4W2R2 - 4 (3 \%). У 41 (30,8 \%) пацієнта рецидив грижі виник упродовж року після операції, у 62 (46,6 \%) - на 2-й рік і у 30 (22,6 \%) - через 3 і більше років. У 91 (68,4 \%) пацієнта була наявна супутня патологія.

Результати досліджень та їх обговорення. Причинами рецидиву гриж були: діастаз прямих м’язів живота, який не ліквідували при виконанні попередньої операції, малий розмір імплантанту відносно грижового дефекту, технічні похибки при його фіксації, “прорізання” фіксуючих швів з утворенням дефектів в опорних тканинах передньої черевної стінки (ПЧС), відрив сітки від дистрофічно змінених опорних тканин ПЧС, тяжкий перебіг раннього післяопераційного періоду з тривалим підвищенням внутрішньочеревного тиску та запальні ускладнення в післяопераційному періоді з секвестрацією сітки, утворенням лігатурних нориць, відривом та “скручуванням” сітки.

При виборі способу повторної реконструкції ПЧС ми враховували морфо-функціональні зміни тканин передньої черевної стінки, наявність діастазу прямих м'язів живота, розміри і правильність розміщення раніше вшитого імплантату, розмір грижового дефекту та об’єм грижового випину.

У післяопераційному періоді у 3 (2,25 \%) пацієнтів спостерігались клінічні ознаки серцево-легеневої недостатності, які виникли на 2-3 добу після операції і були ліквідовані стандартними консервативними заходами. Ускладнення запального характеру мали місце у 6 (4,5 \%). Віддалені результати лікування рецидивних ПГЖ вивчені шляхом повторних оглядів у 102 пацієнтів у строки від 1 до 10 років, рецидиву грижі не виявлено.
\end{abstract}

Ключові слова: післяопераційна грижа живота; алопластика; рецидив грижі; вибір способу реконструкції; імплантат; профілактика запальних ускладнень.

Постановка проблеми і аналіз останніх досліджень та публікацій. Збільшення чисельності й складності виконання операційних втручань на органах черевної порожнини призвело до зростання кількості післяопераційних гриж живота (ПГЖ) [4]. Інтенсивний розвиток мініінвазивних, ендоскопічних технологій у хірургії зменшив кількість хірургічних втручань, виконаних лапаротомним доступом, проте їх відсоток залишається досить високим. За даними літератури, 3-19 \% усіх операційних втручань лапаротомним доступом ускладнюються формуванням післяопераційної грижі живота [1-4]. Сьогодні ПГЖ становлять 20-26 \% від загальної кількості гриж живота і посідають друге місце після пахвинних гриж [3, 4].

Зрозуміло, що кожне операційне втручання повинно виконувати основні задачі, а саме: остаточне або досить тривале усунення патології та максимально швидка фізична реабілітація, тобто, повинно мати високий ступінь медико-соціальної ефективності. Стосовно ПГЖ операційне втручання повинно забезпечувати відсутність грижі та iï рецидиву і сприяти швидкій фізичній і соціальній реабілітації пацієнта. Виникнення ПГЖ або рецидиву грижі, особливо у пацієнтів працездатного віку, $є$ не тільки медичною проблемою лікування таких хворих, а і значною соціально-економічною. На сьогодні результати лікування пацієнтів із ПГЖ не можна вважати задовільними через досить високий відсоток рецидивів 4,3-46 \% [3, 4]. Тому лікування хворих із післяопераційною грижею живота залишається актуальною проблемою сучасної хірургії. Так, навіть після використання допоміжних синтетичних матеріалів для алопластики, за даними вітчизняних і зарубіжних авторів, відсоток рецидивів ПГЖ становить 3,7-20 \% [1$7,9,10]$. Виникає необхідність аналізу причин таких незадовільних результатів лікування хворих 3 ПГЖ, та пошуку шляхів оптимізації алгоритму лікування пацієнтів з даною патологією.

Мета роботи: вивчення причин виникнення рецидиву ПГЖ після алопластики і розробка практичних рекомендацій для поліпшення результатів хірургічного лікування пацієнтів із даною патологією. 
Матеріали і методи. За період 32004 до 2019 р. у Київському міському центрі хірургії гриж живота з приводу рецидивної ПГЖ після алогерніопластики було прооперовано 133 пацієнта: чоловіків було 23 (17,3 \%), жінок - 110 (82,7 \%). Середній вік пацієнтів склав $(59,4 \pm 0,8)$ року. Пацієнти з ПГЖ за класифікацією SWR [8] розподілилися таким чином: хворих із M2-3W1R1 було 80 (60,15 \%), M3-5W2R1 - 40 (30,1 \%), M3-5W3R2 3 (2,25 \%), L3W2R1 - 6 (4,5 \%), L4W2R2 - 4 (3\%). У 41 (30,8 \%) пацієнта рецидив грижі виник упродовж року після операції, у 62 (46,6 \%) - на 2-й рік і у 30 (22,6 \%) - через 3 і більше років. У 91 (68,4 \%) пацієнта була наявна супутня патологія (ожиріння, цукровий діабет, ішемічна хвороба серця, хронічні обструктивні захворювання легень, варикозне розширення вен ніг).

Вид рецидиву та спосіб попередньої пластики в більшості випадків визначали безпосередньо під час виконання самої операції. Оскільки у виписних документах пацієнтів спосіб виконаної операції вказувався як алогерніопластика, без інформації про методику розташування імплантату та його розмірів, важливим було оцінити розміри i правильність розміщення раніше вшитого імплантату для визначення подальшої тактики операції.

У комплекс передопераційного обстеження хворих із ПГЖ входили: клінічне, лабораторне, рентгенологічне, функціональне, ендоскопічне та ультрасонографічне дослідження органів черевної порожнини і ділянки грижового дефекту та грижового випину. Пацієнтам із грижами W3-4 для профілактики абдомінального компартмен-синдрому проводили максимальне очищення кишечника і призначали безшлакову дієту. Для адаптації до підвищення внутрішньочеревного тиску (ВЧТ) виконували бандажну компресію живота у пацієнтів із вправимими грижами або використовували тягаря на живіт з частково вправимими. Ефективність підготовки оцінювали за результатами спірографії при моделюванні стану як після виконання реконструкції черевної стінки, тобто вправляли грижовий вміст в черевну порожнину і живіт стискали бандажем. Порівнювали як змінюється дихальний об'єм у пацієнта до бандажної компресії живота і після, він не повинен бути меншим ніж 50 \% від початкового. У пацієнтів із варикозним розширенням вен ніг дотримувались активної флебохірургічної тактики. Так, у пацієнтів із горизонтальним та вертикальним вено-венозним рефлюксом спочатку виконували кросектомію, флебектомію великої підшкірної вени (ВПВ) з корекцією горизонтального рефлюкса, а другим етапом через 4-5 діб виконували герніопластику. При вертикальному вено-венозному рефлексі виконували симультанно спочатку кросектомію, а потім герніопластику. У пацієнта з флотуючим тромбом виконано перев'язку поверхневої стегнової вени. Також виконували стандартну профілактику тромбоемболічних ускладнень. При наявності лігатурних нориць виконували їх санацію. 3 метою профілактики гнійно-запальних ускладнень з боку рани інтраопераційно видаляли “старі” лігатури та дренували рану, призначали антибіотикопрофілактику, нестероїдні протизапальні препарати.

Операційні втручання виконували під загальним знеболенням в поєднанні з постановкою перидурального катетера при грижах W3-4. Як шовний матеріал використовували монофіламентні проленові нитки № 0 або 1.0, а для алопластики поліпропіленові сітки різних виробників. При виконанні операції перевагу віддавали способам, які максимально зменшували можливість підвищення ВЧТ у ранньому післяопераційному періоді. Особливу увагу приділяли прецизійній техніці оперування, зшиванню опорних тканин без натягу, широкому перекриттю сіткою країв грижового дефекту, надійній фіксації протеза, ретельному гемостазу та дренуванню місця імплантації сітки і рани.

\section{Результати досліджень та їх обговорення.} Під час операційного лікування ми встановили, що у 42 (31,6 \%) пацієнтів з грижами M2-3W1R1 причиною рецидиву був діастаз прямих м'язів живота, який не ліквідували при виконанні попередньої операції. У 24 із них грижовий дефект виник над сіткою, у 10 - нижче сітки, і у 8 - 3 латерального боку сітки. У 36 (27,1 \%) хворих з M2-3W2R1 із преперитонеальним розміщенням імплантату рецидив грижі пов'язаний з малим його розміром відносно грижового дефекту або технічними похибками при його фіксації. У 2 (1,5 \%) пацієнтів з M2-3W1R1 рецидив грижі виник по периметру імплантату внаслідок “прорізання” фіксуючих швів 3 утворенням дефектів в опорних тканинах передньої черевної стінки (ПЧС). У 19 (14,3%) пацієнтів з M3-5W2R1 і у 4 (3 \%) з L4 W2R2 причиною рецидиву був відрив сітки від дистрофічно змінених опорних тканин ПЧС. У 21 (15,8 \%) пацієнта з M3-5W2R1, у 3 (2,25 \%) з M3-5W2-3R2, у 6 (4,5 \%) з L3W2R1 причиною рецидиву грижі були: тяжкий перебіг раннього післяопераційного періоду з тривалим підвищенням ВЧТ та запальні ускладнення в післяопераційному періоді з секвестрацією сітки, утворенням лігатурних нориць, відривом та “скручування” сітки.

При виборі способу повторної реконструкції ПЧС ми враховували морфо-функціональні змі- 


\section{З ДОСВІДУ РОБОТИ}

ни тканин передньої черевної стінки, наявність діастазу прямих м’язів живота, розміри і правильність розміщення раніше вшитого імплантату, розмір грижового дефекту та об’єм грижового випину. Так, при визначенні розміру сітки необхідно враховувати те, що імплантат повинен перекривати грижовий дефект не менше ніж на 5 сантиметрів по його периметру [10]. У 51 пацієнта при реконструкції ПЧС ми видалили сітку, яка була імплантована при попередній операції. Причинами видалення імплантату були: дислокація, зморщування і скручування сітки, контакт імплантату з органами черевної порожнини та часткова секвестрація сітки (відторгнення). При задовільному стані опорних тканин у 75 (56,4%) пацієнтів з грижою M2-3W1R1 виконали реконструкцію за способом sublayretromuscle, у 40 (30,1 \%) з грижою M3-5W2R1 - sublaypreperitoneal, y 2 (1,5 \%) з M35W3R2 - inlay-sublaypreperitoneal, y 5 (3,8 \%) 3 L3 W2R1 - sublaypreperitoneal, y 4 (3 \%) 3 L4 W2R2 inlay-sublaypreperitoneal, i y 5 (3,8 \%) з M3-5W3R2 та 2 (1,5 \%) з L3W3R1 виконано інтраабдомінальне розміщення композитної сітки.

У післяопераційному періоді у 3 (2,25 \%) пацієнтів спостерігались клінічні ознаки серцеволегеневої недостатності, які виникли на 2-3 добу після операції і були ліквідовані стандартними консервативними заходами. Ускладнення запального характеру мали місце у 6 (4,5 \%). Віддале-

\section{СПИСОК ЛІТЕРАТУРИ}

1. Богдан В. Г. Современные аспекты реконструктивно-восстановительной хирургии послеоперационных грыж живота / В. Г. Богдан, М. Ю. Гаин. - Минск : БелМАПО, 2017. - 233 с. 2. Хирургическое лечение пациентов с большими и гигантскими послеоперационными вентральными грыжами / А. С. Ермолов, Д. А. Благовестнов, А. К. Алексеев [и др.] // Хирургия. Журнал им. Н. И. Пирогова. - 2019. - № 9. - С. 38-43. 3. Современный взгляд на лечение послеоперационных грыж брюшной стенки / Б. Ш. Гогия, Р. Р. Аляутдинов, А. А. Копыльцов, Т. В. Токарева // Consilium Medicum. 2016. - № 2. - С. 6-8.

4. Фелештинський Я. П. Післяопераційні грижі живота : монографія / Я. П. Фелештинський. - К. : ТОВ “Бізнес-Логіка”, 2012. - 200 c.

5. Correlation between early surgical complications and readmission rate after ventral hernia repair / D. Kokotovk, H. Sjo-

\section{REFERENCES}

1. Bogdan, V.G., \& Gain, M.Yu. (2017). Sovremennyye aspekty rekonstruktivno-vosstanovitelnoy khirurgii posleoperatsionnykh gryzh zhivota [Modern aspects of reconstructive surgery for incisional abdominal hernias]. Minsk: BelMAPO [in Russian]. ні результати лікування рецидивних ПГЖ вивчені шляхом повторних оглядів у 102 пацієнтів у строки від 1 до 10 років, рецидиву грижі не виявлено.

Висновки. 1. Основною причиною виникнення рецидиву ПГЖ у 31,6 \% пацієнтів був неліквідований діастаз прямих м’язів живота, у 28,6 \% малий розмір імплантату відносно грижового дефекту та технічні помилки при його фіксації.

2. Запальні ускладнення в рані та тривале підвищення внутрішньочеревного тиску в післяопераційному періоді стали причиною рецидиву ПГЖ у 22,5 \% пацієнтів.

3. Морфо-функціональні вікові та дистрофічні зміни тканин передньої черевної стінки як результат раніше перенесених операцій сприяли виникненню рецидиву ПГЖ у 17,3 \% пацієнтів.

4. Комплексний підхід до передопераційної підготовки хворих з ПГЖ, вибір оптимального способу реконструкції та розмірів імплантату, прецизійна техніка оперування з профілактикою запальних ускладнень, дадуть змогу значно зменшити можливість виникнення рецидиву захворювання.

5. Пацієнти з рецидивними грижами живота повинні оперуватись у спеціалізованих центрах.

Перспективи подальших досліджень. Дана проблема потребує подальшого вивчення з відстеженням більш тривалих віддалених результатів.

lander, I. Gogenur, F. Helgstrand // Hernia. - 2017. - Vol. 21 (4). - P. 563-568.

6. Millikan K. W. Incisional hernia repair / K. W. Millikan // Surg. Clin. North Am. - 2003. - Vol. 83 (5). - P. 1223-1234.

7. Cassar K. Surgical treatment of incisional hernia / K. Cassar, A. Munro // Br. J. Surg. - 2002. - Vol. 89 (5). - P. 534-545. 8. Classification of incisional hernias of the abdominal wall / F. E. Muysoms, M. Miserez, F. Berrevoet [et al.] // Hernia. 2009. - Vol. 13 (4). - P. 407-414.

9. Classification and surgical treatment of incisional hernia. Results of an experts' meeting / M. Korenkov, A. Paul, J. P. Chevrel [et al.] // Langenbecks Arch. Surg. - 2001. - Vol. 386 (1). P. 65-73.

10. Chan G. A review of incisional hernia repairs. Preoperative weight loss and selective use of the mesh repair / G. Chan, C. K. Chan // Hernia. - 2005. - Vol. 9 (1). - P. 37-41. 
nias]. Khirurgiya. Zhurnal im. N.I. Pirogova - Surgery. Journal named after N.I. Pyrogov, 9, 38-43 [in Russian].

3. Gogiya, B.Sh., Alyautdinov, R.R., Kopyltsov, A.A., \& Tokareva, T.V. (2016). Sovremennyy vzglyad na lecheniye posleoperatsionnykh gryzh bryushnoy stenki [Modern view of the treatment of incisional hernias of the abdominal wall]. Consilium Medicum, 2, 6-8 [in Russian].

4. Feleshtynskyi, Ya.P. (2012). Pisliaoperatsiini hryzhi zhyvota: monohrafiia [Postoperative abdominal hernias: Monograph]. Kyiv: TOV "Biznes-Lohika" [in Ukrainian].

5. Kokotovk, D., Sjolander, H., Gogenur, I., \& Helgstrand, F. (2017). Correlation between early surgical complications and readmission rate after ventral hernia repair. Hernia, 21 (4), 563-568. DOI: 10.1007/s10029-017-1606-y.

6. Millikan, K.W. (2003). Incisional hernia repair. Surg. Clin. North Am., 83 (5), 1223-1234. DOI: 10.1016/S0039-
6109(03)00129-4.

7. Cassar, K., \& Munro, A. (2002). Surgical treatment of incisional hernia. Br. J. Surg., 89 (5), 534-545. DOI: 10.1046/j.13652168.2002.02083.x.

8. Muysoms, F.E., Miserez, M., Berrevoet, F., Campanelli, G., Champault, G.G., Chelala, E., ..., \& Kingsnorth, A. (2009). Classification of incisional hernias of the abdominal wall. Hernia, 13 (4), 407-414. DOI: 10.1007/s10029-009-0518-x.

9. Korenkov, M., Paul, A., Sauerland, S., Neugebauer, E., Arndt, M., Chevrel, J.P., ..., \& Simmermacher, R.K. (2001). Classification and surgical treatment of incisional hernia. Results of an experts' meeting. Langenbecks Arch. Surg., 386 (1), 65-73. DOI: $10.1007 / \mathrm{s} 004230000182$.

10. Chan, G., \& Chan, C.K. (2005). A review of incisional hernia repairs. Preoperative weight loss and selective use of the mesh repair. Hernia, 9 (1), 37-41. DOI: 10.1007/s10029-004-0270-1.

Отримано 10.02.21

Електронна адреса для листування: ABSavich@i.ua

S. M. PIOTROVICH, O. V. VASILCHUK, V. S. ANDRIIETS

O. Bohomolets National Medical University,

Kyiv City Center of Abdominal Hernia Surgery

\section{BASIC PRINCIPLES OF SURGICAL TREATMENT OF RECURRENCE OF POSTOPERATIVE ABDOMINAL HERNIA AFTER ALLOPLASTY}

The aim of the work: to study the causes of relapse of postoperative abdominal hernia (PAH) after alloplasty and development of practical recommendations for improving the results of surgical treatment of patients with this pathology.

Materials and Methods. During the period from 2004 to 2019, 133 patients underwent surgery at the Kyiv City Center of Abdominal Hernia Surgery of recurrent PAH after allohernioplastic surgery. Men were 23 (17.3 \%), women - 110 (82.7 \%). The average age of patients was (59.4 \pm 0.8$)$ years. Patients with PAH by SWR classification [8] were distributed as follows: patients with M2-3W1R1 were 80 (60.15 \%), M3-5W2R1 - 40 (30.1 \%), M3-5W3R2 - 3 (2.25 \%), L3W2R1 - 6 (4.5 \%), L4W2R2 - 4 (3 \%). In 41 (30.8 \%) patients the recurrence of hernia occurred in the 1st year after surgery, in 62 (46.6 \%) - in the 2nd year and in 30 (22.6 \%) - in 3 or more years $91(68.4 \%)$ patients had concomitant pathology

Results and Discussion. The causes of recurrence of hernia were: the diastase of direct moves of the abdomen, which was not eliminated when performing a preliminary operation, a small size of the implant relative to the hernia defect, technical errors in its fixation, "cutting" fixing seams with the formation of defects in the support tissues of the anterior abdominal wall (AAW), a breakdown of the mesh from dystrophic changed support tissues of the AAW, a severe course of an early postoperative period with a prolonged increase in intra-abdominal pressure, and inflammatory complications in the postoperative period with a sequestration of the mesh, the formation of ligature fistula, separation and "twisting" mesh.

When choosing a method for re-reconstruction of the AAW, we took into account the morpho-functional changes in the tissues of the anterior abdominal wall, the presence of the diastasis of the abdominal tissues, the size and correctness of the placement of previously sewn implants, the size of the hernia defect and the size of the hernial bulging.

In the postoperative period, 3 (2.25\%) patients had clinical signs of pulmonary heart failure that occurred 2-3 days after surgery and were eliminated by standard conservative measures. Inflammatory complications occurred in 6 (4.5 \%). Long-term results of treatment of recurrent PAH were studied by repeated examinations in 102 patients in the period from 1 to 10 years, no recurrence of hernia was detected.

Key words: postoperative abdominal hernia; alloplasty; recurrent hernia; choosing a method of reconstruction; implant; prevention of inflammatory complications. 


\section{С. М. ПИОТРОВИЧ, А. В. ВАСИЛЬЧУК, В. С. АНДРИЕЦ}

Национальный медицинский университет имени А. А. Богомольца

Центр хирургии грыж живота, Киев

\section{БАЗОВЫЕ ПРИНЦИПЫ ХИРУРГИЧЕСКОГО ЛЕЧЕНИЯ РЕЦИДИВА ПОС.ЛЕОПЕРАЦИОННЫХ ГРЫЖ ЖИВОТА ПОС.ЛЕ АЛ.ЛПЛАСТИКИ}

Цель работы: изучение причин возникновения рецидива послеоперационных грыж живота (ПГЖ) после аллопластики и разработка практических рекомендаций по улучшению результатов хирургического лечения пациентов с данной патологией. Материалы и методы. За период с 2004 по 2019 гг. в Киевском городском центре хирургии грыж живота по поводу рецидивной ПГЖ после аллогерниопластики было прооперировано 133 пациента: мужчин - 23 (17,3 \%), женщин - 110 (82,7 \%). Средний возраст пациентов составлял $(59,4 \pm 0,8)$ года. Пациенты с ПГЖ по классификации SWR [8] распределились следующим образом: больных с M2-3W1R1 было 80 (60,15 \%), M3-5W2R1 - 40 (30,1 \%), M3-5W3R2 - 3 (2,25 \%), L3W2R1 - 6 (4,5 \%), L4W2R2 4 (3 \%). B 41 (30,8 \%) пациента рецидив грыжи возник в первый год после операции, у 62 (46,6 \%) - на 2-й год и у 30 (22,6 \%) - через 3 и более лет. В 91 (68,4 \%) пациента имелась сопутствующая патология.

Результаты исследований и их обсуждение. Причинами рецидива грыж были: диастаз прямых мышц живота, не ликвидированный при выполнении предыдущей операции, малый размер имплантата относительно грыжевого дефекта, технические погрешности при его фиксации, “прорезывание” фиксирующих швов с образованием дефектов в опорных тканях передней брюшной стенки (ПБС), отрыв сетки от дистрофически измененных опорных тканей ПБС, тяжелое течение раннего послеоперационного периода с длительным повышением ВБД и воспалительные осложнения в послеоперационном периоде с отторжением сетки, образованием лигатурных свищей, отрывом и “скручивания” сетки.

При выборе способа повторной реконструкции ПБС мы учитывали морфо-функциональные изменения тканей передней брюшной стенки, наличие диастаза прямых мышц живота, размеры и правильность размещения ранее вшитого импланта, размер грыжевого дефекта и объем грыжевого выпячивания.

В послеоперационном периоде у 3 (2,25 \%) пациентов наблюдались клинические признаки сердечно-легочной недостаточности, возникшие на 2-3 сутки после операции и были ликвидированы стандартными консервативными мерами. Осложнения воспалительного характера имели место у 6 (4,5 \%). Отдаленные результаты лечения рецидивирующих ПГЖ изучены путем повторных осмотров в 102 пациентов в сроки от 1 до 10 лет. Рецидивов грыж не выявлено.

Ключевые слова: послеоперационная грыжа живота; аллопластика, рецидив грыжи; выбор способа реконструкции; имплантат; профилактика воспалительных осложнений. 